http://dx.doi.org/10.15762/ZH.2015.33

BOGUSEAW DYBAŚ

(Stacja Naukowa PAN w Wiedniu)

\title{
PLAN OBLEZŻENIA TORUNIA W ROKU 1658 Z WIEDEŃSKIEGO ARCHIWUM WOJNY
}

Słowa kluczowe: wojny szwedzkie, kartografia wojskowa, fortyfikacje, armia cesarska, armia polska, Wisła, XVII w., wojna lat 1655-1660, Johan Eusebius Mayer

Epoka nowożytna to czas, gdy kształtują się nowoczesne metody odzwierciedlania w kartografii i ikonografii przestrzeni otaczającej człowieka, w tym zwłaszcza zagęszczonej przestrzeni miejskiej. Jak to często w historii bywa, także w tym obszarze działania podejmowane w związku $\mathrm{z}$ toczonymi wojnami miały charakter przodujący. Raczej nie powinno to dziwić, bo poniekąd $\mathrm{z}$ definicji informacja na potrzeby działań militarnych winna mieć charakter pewny. Od tego zależał i ewentualny sukces, i ponoszone $w$ walce straty, i wiele innych kwestii.

W tym kontekście można powiedzieć, że w rozwoju kartografii dotyczącej Torunia przełomowe znaczenie miały wojny toczone w XVII i na początku XVIII w., co potwierdza postawioną wyżej tezę. Trzeba też przyznać, że początki kartografii Torunia są bardzo dobrze zbadane, przede wszystkim dzięki znakomitym artykułom Andrzeja Tomczaka ${ }^{1}$. Autor ten, pracując nad katalogiem dawnych planów Torunia, przeprowadził rozległe kwerendy w zbiorach europejskich, których wyniki były wykorzystywane m.in. w badaniach nad nowożytnymi fortyfikacjami Torunia w epoce nowożytnej². Były też znakomitym punktem wyjścia do szczegółowych studiów nad poszczególnymi zabytkami kartografii ${ }^{3}$. Taki też charakter, bardziej może publikacji źródłowej, ma ten tekst, dotyczący jednego z planów powstałych w związku z oblężeniem przez wojska polsko-austriackie w $1658 \mathrm{r}$. Torunia, bronionego przez szwedzki garnizon.

\footnotetext{
${ }^{1}$ Andrzej Toмсzaк, O najdawniejszych planach Torunia, Zapiski Historyczne, t. 45: 1980, z. 3 , s. 101-128; idem, Źródła kartograficzne do oblężenia przez Szwedów Torunia w 1703 r., ibid., t. 47: 1982, z. 4, s. $227-238$.

${ }^{2}$ Jerzy Stankiewicz, Twierdza Toruń, cz. I, ibid., t. 37: 1972, z. 4, s. 9-68; Bogusław Dybaś, Początki nowożytnych fortyfikacji Torunia w świetle źródeł pisanych, ibid., t. 59: 1994, z. 1, s. 29-44.

${ }^{3}$ Jak np.: Bogusław DyвAś, Zaginiony plan Torunia z połowy XVII wieku, Folia Toruniensia, t. 1: 2000, s. 59-68.
} 
Należy zauważyć, że A. Tomczak zbierał i publikował plany w latach sześćdziesiątych i siedemdziesiątych XX w., gdy techniki kopiowania materiału archiwalnego, zwłaszcza kartografii, były bardziej skomplikowane i kosztowne, natomiast poziom techniczny reprodukcji $\mathrm{z}$ takiego materiału w polskiej literaturze naukowej stał na zatrważająco niskim poziomie. Dzisiaj zarówno kopiowanie jest prostsze, jak i możliwość publikacji materiału kartograficznego na wysokim poziomie zdecydowanie dostępniejsza4. Stąd też obecnie publikacje źródeł kartograficznych z samych względów technicznych mają dużą wartość jako materiał źródłowy dla historyka (pomijam tu publikacje elektroniczne kartografików, często dostępne też $\mathrm{w}$ internecie).

Oblężenie bronionego przez szwedzki garnizon Torunia w 1658 r., prowadzone przez sojusznicze wojska polsko-austriackie, było ważnym wydarzeniem zarówno w wojnie polsko-szwedzkiej w latach 1655-1660, jak i w historii miasta. Jest też ono dość dobrze zbadane w starszej i nowszej literaturze ${ }^{5}$. To zwalnia od szczegółowego omawiania wydarzeń wojennych i pozwala na ograniczenie się do podstawowych informacji. Podjęcie ataku na Toruń, jedną z najsilniejszych w tym momencie szwedzkich twierdz na linii Wisły (bronioną przez liczący ponad 2500 żołnierzy garnizon), oznaczało - po pokonaniu w 1657 r. Jerzego Rakoczego i opanowaniu Krakowa - nowy jakościowo etap w wojnie toczonej ze Szwecją, teraz już w sojuszu i z militarnym wsparciem wojsk cesarskich, a także Brandenburgii. W przypadku Torunia w grę wchodziła przede wszystkim współpraca z Austriakami. Pierwsze próby zdobycia Torunia, właśnie ze strony Austriaków, nastąpiły już jesienią $1657 \mathrm{r}$., ale nie były skuteczne. W rezultacie opanowanie tej silnej twierdzy odłożono do wiosny 1658 r., chcąc je odpowiednio przygotować (zgromadzenie odpowiedniej liczby piechoty, artylerii, budowa mostu pontonowego przez Wisłę).

Komplikacja sytuacji politycznej sprawiła, że dopiero na początku czerwca 1658 r. rada wojenna sprzymierzonych (Rzeczpospolita, cesarz, elektor brandenburski) przyjęła plan ataku na Toruń, przeznaczając do tego celu wojska cesarskie generała Jean-Louis’a Raduit de Souches, polskie generała Krzysztofa Grodzickiego i pisarza polnego koronnego Jana Sapiehy oraz brandenburskie pod wodzą księcia Bogusława Radziwiłła ${ }^{6}$. Austriacy stanęli pod Toruniem 2 VII 1658 r., Polacy w ko-

\footnotetext{
${ }^{4} \mathrm{~W}$ przypadku źródeł kartograficznych do dziejów Torunia za symbol przełomu, jaki w tym zakresie dokonał się w ciągu ostatniego ćwierćwiecza, można uznać: Atlas historyczny miast polskich, t. 1: Prusy Królewskie i Warmia, z. 2: Toruń, red. Antoni Czacharowski, opr. historyczne Janusz TANDECKI, opr. kartograficzne Zenon KozieŁ, Toruń 1995. Zebrane w tej publikacji reprodukcje map są i duże, i na znakomitym poziomie poligraficznym.

${ }^{5}$ Już przed wojną powstała obszerna monografia oblężenia: Tadeusz NowaK, Oblężenie Torunia w roku 1658, Toruń 1936. Krótsze i syntetyczne przedstawienie: Bogusław DyBAś, Dzieje wojskowe Torunia w latach 1548-1660, [in:] Historia Torunia, red. Marian Biskup, t. 2, cz. 2: $W$ czasach renesansu, reformacji i wczesnego baroku (1548-1660), Torun 1994, s. 160-167. Na temat fortyfikacji Torunia w tym czasie obszernie: J. STANKIEWICZ, op.cit., s. 47-57.

${ }^{6} \mathrm{O}$ kontekstach politycznych i militarnych tych decyzji obszernie zob. w: Eckardt OpITz, Österreich und Brandenburg im Schwedisch-Polnischen Krieg 1655-1660. Vorbereitung und Durchführung der Feldzüge nach Dänemark und Pommern, Boppard am Rhein 1969, s. 79-115. Tu trzeba odnoto-
} 
lejnych dniach i tygodniach, rozpoczynając blokadę miasta i wstępne prace oblężnicze. Losy kampanii jednak się ważyły, ponieważ oczekiwano ponownego ataku króla szwedzkiego Karola Gustawa na Prusy po pokoju w Roskilde z Danią. Z tego względu B. Radziwiłł, obawiając się ataku Szwedów na Prusy Książęce, nie dotarł pod Toruń, a wódz cesarski Raimondo Montecuccoli rozważał okolice Torunia jako miejsce walnej bitwy z Karolem Gustawem, gdyby ten wylądował w Prusach Królewskich. Sytuację wyjaśnił kolejny atak króla szwedzkiego na Danię, której sprzymierzeni wysłali posiłki (m.in. polską dywizję Stefana Czarnieckiego), natomiast sejm obradujący w Warszawie latem $1658 \mathrm{r}$. postanowił skierować pod Toruń - dla wzmocnienia sił oblężniczych - dywizję hetmana polnego koronnego Jerzego Sebastiana Lubomirskiego. Całość tych sił zgromadziła się pod Toruniem na przełomie września i października i liczyła ostatecznie około 23 tysiące żołnierzy ${ }^{7}$. Wprawdzie pod Toruń przybył także król Jan Kazimierz z dworem, ale faktycznym dowódcą sprzymierzonych był J.S. Lubomirski.

Struktura armii oblężniczej (faktycznie przewaga kawalerii w składzie, nieliczna artyleria - 40 dział, przeważnie do tego polowych) nie pozwalała na regularne oblężenie na dużą skalę. Działania prowadzone w październiku wykazały wprawdzie słabe punkty toruńskich fortyfikacji, głównie na froncie zachodnim, i w związku z tym możliwość prowadzenia regularnego oblężenia, ale na początku listopada J.S. Lubomirski przeforsował przeprowadzenie szturmu. Doszło do niego w nocy z 16 na 17 listopada. W wyniku krwawych walk Torunia wprawdzie nie zdobyto (opanowano bastiony od strony zachodniej i północno-zachodniej), ale kapitulacja Szwedów była tylko kwestią czasu. Po gwałtownym ostrzale 14 grudnia następnego dnia rozpoczęły się rozmowy kapitulacyjne, 22 grudnia ustalono, łagodne zresztą dla Szwedów, warunki kapitulacji, 30 grudnia Szwedzi wymaszerowali z miasta, a 1 I 1659 r. uroczyście wjechał do Torunia król Jan Kazimierz.

wać, że tematem rozważań E. Opitza są przede wszystkim relacje cesarsko-brandenburskie i w tym kontekście kampanie duńskie; oblężenie Torunia jest raczej na marginesie jego rozważań, nie cytuje on książki T. Nowaka, chociaż przytacza kilka innych prac polskojęzycznych (m.in. Władysława Czaplińskiego). Cały przebieg oblężenia Torunia widzi więc wyłącznie w kontekście udziału w nim kontyngentu cesarskiego (ibid., s. 104-105).

${ }^{7}$ Jan Wimmer (cyt. za: B. Dyваś, Dzieje wojskowe Torunia, s. 163) wylicza, że wojska polskie liczyły 9400 piechoty, 2270 dragonii i 7000 jazdy, cesarskie zaś - 1650 piechoty oraz 3000 jazdy i dragonii. Nieco inne dane, jeśli chodzi o cesarski kontyngent pod wodzą generała Jean-Louis’a Raduit de Souches (w momencie, gdy został on wysłany pod Toruń), podaje E. OpITz, op.cit., s. 104. Kontyngent ten składał się z sześciu regimentów, w tym jednego piechoty samego de Souches, trzech jazdy Heistera, Ratschina i Knigge oraz dwóch dragońskich Spancko i Flettingera. Regiment pieszy liczył 1400 żołnierzy, kawaleryjskie w sumie 1500, a dragońskie - 1250 ludzi. Kontyngent ten został wzmocniony później (w sierpniu i na początku września 1658 r.) regimentem pieszym de Nicoli oraz pięcioma kompaniami drugiego regimentu de Mersa (T. NowAK, op.cit., s. 19, 36), ale oczywiście z biegiem czasu stopniał i wedle T. Nowaka (ibid., s. 40) liczył w momencie przybycia pod Toruń na przełomie września i października Jana Kazimierza i J.S. Lubomirskiego 1380 piechoty i 2400 jazdy oraz dragonii, czyli około 3800 żołnierzy.

${ }^{8}$ Syntetyczne omówienie oblężenia zob. w: B. Dyвaś, Dzieje wojskowe Torunia, s. 163-166. 
Będący przedmiotem tej edycji plan ilustrujący oblężenie Torunia w końcu 1658 r., przechowywany w wiedeńskim Archiwum Wojny (Kriegsarchiv) ${ }^{9}$, był oczywiście znany wcześniej badaczom, m.in. Jerzemu Stankiewiczowi i A. Tomczakowi. Nie wydaje się jednak, by mieli oni możliwość go w pełni wykorzystać czy analizować $w$ oryginale ${ }^{10}$. Jest to jak najbardziej zrozumiałe, jeśli m.in. uświadomimy sobie gigantyczne wręcz rozmiary planu $-172 \times 84,5 \mathrm{~cm}$. Była to z pewnością dodatkowa zapora, by z tego źródła skorzystać, jeśli nie było możliwości osobiście spędzić odpowiedniej ilości czasu w wiedeńskim archiwum. Jesienią 2012 r. skan planu w ramach współrealizowanego przez niego grantu zamówił za moim pośrednictwem nieżyjący już niestety Jacek Bachanek, który prowadził kwerendy na temat topografii nowożytnego Torunia i okolic. Uznał, że jest to jedyny plan Torunia o takich gabarytach wykonany przed połową XIX w. ${ }^{11}$

\footnotetext{
${ }^{9}$ Österreichisches Staatsarchiv Wien, Kriegsarchiv, Kartensammlung H III c 5, Belagerung der Königl. Stadt Thorn 1658.

${ }^{10}$ Plan nie był raczej znany Tadeuszowi Nowakowi, który korzystał ze zbiorów wiedeńskich, ale planu wśród wykorzystanych źródeł nie wymienia (T. Nowak, op.cit., s. 5). Jerzy Stankiewicz wymienia plan wśród innych, podobnie pokazujących stan fortyfikacji Torunia, ale dokładniej go nie analizuje. Nadmienia natomiast, że dysponował nim dzięki uprzejmości Andrzeja Tomczaka (J. STANKIEWICZ, op.cit., s. 51). W chronologicznie późniejszym artykule o najdawniejszych planach Torunia A. Tomczak reprodukuje plan (a właściwie jego fragment), poświęca mu akapit w części opisowej i odnotowuje go w katalogu planów (A. ToмCZAK, O najdawniejszych planach Torunia, s. 109, tu reprodukcja i krótka informacja; s. 122, poz. 14 katalogu). Autor jednak nie miał, jak się wydaje, możliwości analizowania oryginału, tylko posługiwał się dostarczoną fotografią, która prócz dość kiepskiej jakości ujmuje tylko część planu (około 2/3) - miasto i jego otoczenie, nie obejmuje natomiast górnego biegu Wisły po Złotorię i ujście Drwęcy oraz przerzucony za zakolem Wisły przez sprzymierzonych most pontonowy. Jako autora A. Tomczak podaje (ibid., s. 109) kapitana Jana Ezechiela Mayera, tymczasem w podpisie na mapie drugie imię autora jest zapisane jako: „Euseb[ius]”. W katalogu brak dość kluczowej dla analizy tego planu informacji o jego szczególnych rozmiarach. Nie jest też właściwa data sporządzenia planu, która w katalogu jest podana jako: „in September”. Tymczasem jej zapis jest inny: „in Xbre”, czyli w grudniu. A. Tomczak przywołuje informację o planie z pracy Ludomira Sawickiego, która jest jednak niezwykle lakoniczna: „Mayer Belägerung der Königl: Stadt Thorn sambt allen zuegehörigen Werckenund Approchen" (Ludomir SAWICKI, Spis map Archiwum Wojennego $w$ Wiedniu odnoszacych się do ziem polskich, [in:] Przyczynki do bibliografii kartograficznej ziem polskich, wyd. Ludomir SAWICKI, Warszawa 1920, s. 172, nr 2006).

${ }^{11}$ Korespondencja z Jackiem Bachankiem z września-listopada 2012 r. w archiwum autora. Co do okoliczności zamówienia skanu zob. list z 28 IX 2012 r.: „Witaj Bogusławie, Zespół do badań nad średniowiecznym i nowożytnym Toruniem pracuje nad projektem Rozwój przestrzenny Torunia do poczatków XIX wieku. Do moich zadań należy zbadanie zmian jakie zachodziły na obszarze przedmieść, m.in. zmiany sieci hydrologicznej. W artykule prof. Tomczaka [o najdawniejszych planach Torunia - B.D.] znalazłem informację, że w zbiorach wiedeńskiego Kriegsarchiv znajduje się plan Torunia i okolicy z 1658 roku. W artykule tym jest kopia tego planu, niestety mało czytelna. Pozwoliła jednak dostrzec ważne elementy topografii. Ten plan jest pierwszym bogatym w szczegóły topograficzne znajdujące się na przedmieściach i Mokrym, w tym cieki wodne. Kieruję do Ciebie prośbę o złożenie zamówienia na wykonanie scanu tego planu. Jeżeli spełnienie mojej prośby jest możliwe, to o konkretach (sygnatura, konto bankowe) napiszę w następnym emailu. Wszystkie koszty związane z wykonaniem scanu zostałyby sfinansowane ze środków grantu. Pozdrawiam Jacek Bachanek". Skan wykonany na zlecenie Jacka Bachanka w formacie *.tiff o rozdzielczości 400 dpi ma objętość ponad $1 \mathrm{~GB}$.
} 
Już ze względu na rozmiary plan jest bardzo ciekawy od strony zarówno przyczyn takiej jego wielkości, jak i m.in. spowodowanych przez to problemów z właściwym przechowywaniem i pojawiającymi się wyzwaniami konserwatorskimi. Ze względu na datę wykonania, w grudniu 1658 r. (czyli na koniec oblężenia), wydaje się, że plan jest raczej jego swoistą dokumentacją i podsumowaniem niż narzędziem bezpośrednio pomocnym w czasie działań oblężniczych ${ }^{12}$. Niestety, mimo intensywnych poszukiwań nie udało się znaleźć bliższych informacji na temat autora planu, kapitana Johanna Eusebiusa Mayera ${ }^{13}$. Można tylko snuć hipotezy, że był on oficerem $z$ otoczenia R. Montecuccolego, dowodzącego wojskami cesarskimi w Rzeczypospolitej, któremu zlecone zostało kartograficzne udokumentowanie jednego z najważniejszych działań podczas tej wojny i udziału w nim wojsk cesarskich $^{14}$.

Wartość planu polega przede wszystkim na tym, że - po części także w związku z rozmiarami - obejmuje on dość swobodnie nie tylko miasto, lecz także w szerokim zakresie jego okolice, zwłaszcza przebieg rzeki Wisły od ujścia Drwęcy oraz prowadzące przez Wisłę przeprawy, zarówno stałe (most toruński), jak i stworzone doraźnie dla potrzeb oblężenia. Dość dokładnie przedstawiono kwatery i pozycje regimentów cesarskich, nieco bardziej pobieżnie obóz i stanowiska armii polskiej. W tym kontekście ukazano też okoliczne osady i punkty topograficzne wokół Toru-

\footnotetext{
${ }^{12}$ Wedle Jana Mokre w drugiej połowie XVII w. „w czasie wojny wodzom naczelnym podlegali rysownicy (dessineurs), których zadaniem było kartograficzne przedstawienie obozów, stanowisk, przemarszów i ruchów wojsk, szkicowanie terenu po obu stronach linii marszu i z rekonesansów oraz obrazowanie pola bitwy w trakcie walk" (Jan MoKRE, Kartografia wojskowa w monarchii austriackiej do końca XVIII wieku oraz rzut oka na wiek XIX i początek XX stulecia, [in:] Galicja na józefińskiej mapie topograficznej 1779-1783 / Die Josephinische Landesaufnahme von Galizien 1779-1783, red. / hrsg. v. Waldemar Bukowski, Bogusław Dybaś, Zdzisław Noga, t. / Bd. 2, cz./ Teil A: Sekcje / Sektionen 31-52, Kraków 2013, s. XV. O dokumentowaniu obiektów fortyfikacyjnych w XVII w. na zlecenie Nadwornej Rady Wojennej, zwłaszcza wzdłuż południowych granic monarchii habsburskiej, przez takich inżynierów, jak Giovanni Pieroni czy Martin Stier, zob. Louis Кroмротіc, Relationen über Fortifikation der Südgrenzen des Habsburgerreiches vom 16. bis 18. Jahrhundert, Hannover 1997.

${ }^{13}$ Nie notuje go niestety praca: Ernst Nischer, Österreichische Kartographen, Wien 1925. Za rozmowy i konsultacje w kwestii identyfikacji J.E. Mayera dziękuję panu mgr. Janowi Mokre, dyrektorowi Oddziału Zbiorów Kartograficznych Austriackiej Biblioteki Narodowej, oraz dr. Robertowi Rillowi kierującemu działem kartografii w wiedeńskim Kriegsarchiv. J. Mokre zwrócił uwagę, że kartografami i inżynierami w armii cesarskiej bardzo rzadko bywali Niemcy (jak J.E. Mayer), przeważnie byli to Włosi lub Francuzi. Zauważył też, że stopień kapitana wydaje się zbyt wysoki jak na jednego z tzw. dessineurs. W zasobach internetowych jedyna informacja na temat osoby o tych imionach i nazwisku to ta o dwóch wpisach do pamiętników Burcharda Grossmanna z 29 VII 1643 r. i Johanna Philipa Mulheisera z 30 VIII 1647 r., znajdujących się w Bibliotece Narodowej Niderlandów (http://www.europeana.eu/portal/record/92065/BibliographicResource_1000056105551.html, dostęp 11 IX 2015 r.). Bliskość czasowa pozwala przypuszczać, że mógł to być późniejszy autor planu oblężenia Torunia.

${ }^{14} \mathrm{Na}$ temat kształtowania się sztabu w armii cesarskiej, a także znaczenia materiału kartograficznego w pracy sztabowej tej epoki zob. Moritz Edler von AngeLI, Zur Geschichte des k.k. Generalstabes, Wien 1876 (nadbitka z czasopisma „Vedette”), s. 6-10.
} 
nia, jak Podgórz, zamek dybowski czy Mokre. To ostatnie najdokładniej, ponieważ głównie tam stacjonowały wojska cesarskie. Plan jest datowany, jak wspomniano, na grudzień 1658 r. i rzeczywiście odzwierciedla sytuację po przeprowadzonym 16 listopada szturmie, podczas którego m.in. zdobyto nieukończone bastiony od zachodu i północnego zachodu.

Jeśli chodzi o stan fortyfikacji Torunia, to plan wiedeński tylko w niewielkim stopniu koryguje dotychczasowy stan wiedzy oparty głównie na tzw. planie kopenhaskim i planie sztokholmskim, a także planie leningradzkim (czyli obecnie: petersburskim $)^{15}$. Odpowiada temu stanowi wiedzy na planie wiedeńskim przebieg bastionów, licząc od wschodu: najpierw mamy bastion zamkowy (czyli wedle J. Stankiewicza Nowy), de facto będący półbastionem, następnie Kawaler z nadszańcem i bastion św. Katarzyny. O ile jednak na wspomnianych planach (kopenhaskim i sztokholmskim, a także leningradzkim) tu kończy się zmodernizowany przez Szwedów i zaopatrzony w przedwał front wschodni, o tyle na planie wiedeńskim do frontu tego jest dołączony jeszcze jeden bastion, zwany przez J. Stankiewicza Odcinkowym (od odcięcia tego frontu od reszty bastionów). Jeśli chodzi o pozostałe cztery bastiony, które nie były dokończone, to jest jedna dość istotna różnica. Otóż ostatni z nich przy Wiśle, w okolicy Bramy Starotoruńskiej, jest na wszystkich trzech planach (kopenhaskim, sztokholmskim i leningradzkim) pełnym bastionem, natomiast na planie wiedeńskim jest to półbastion. Inny nieco jest też na planie wiedeńskim kształt tzw. Szańca Panieńskiego, powstałego na miejscu zburzonego klasztoru benedyktynek. Przede wszystkim jest on jednak cofnięty i znajduje się za linią średniowiecznej fosy, gdy tymczasem na planach kopenhaskim i sztokholmskim jest on położony przed linią fosy i podwiązany do ostatniego z bastionów.

Wydaje się, że zestawienie tych trzech planów (kopenhaskiego, sztokholmskiego i leningradzkiego) z wiedeńskim pozwala dostrzec pewną dynamikę powstawania dokumentacji fortyfikacji miasta $\mathrm{w}$ tym czasie, a także pewne interesujące powiązania między tymi zabytkami kartografii. Otóż pierwsze trzy plany należy raczej widzieć jako szwedzkie koncepcje przekształceń fortyfikacji Torunia i należy je wiązać z rokiem 1656. Tak są one zresztą przeważnie datowane. Natomiast plan wiedeński jest uchwyceniem stanu faktycznego w momencie zakończenia oblężenia. Przy dokładniejszej analizie daje się natomiast dostrzec związek między planem wiedeńskim a tzw. planem włoskim oblężenia ${ }^{16}$. Już A. Tomczak dostrzegł podobieństwo treściowe tego planu do planu wiedeńskiego ${ }^{17}$. Przede wszystkim jednak odnotował on zasadniczą różnicę formalną między obydwoma źródłami,

${ }^{15}$ J. STANKIEWICZ, op.cit., s. 49-55, na s. 48 reprodukcja planu kopenhaskiego; B. DyBAś, Dzieje wojskowe Torunia, s. 161; w tym tomie Historii Torunia jako ilustracja 87 zamieszczona jest reprodukcja planu sztokholmskiego. Plan tzw. leningradzki reprodukuje: A. ToмсzAK, O najdawniejszych planach Torunia, s. 106, il. 2; s. 120, poz. 7 w katalogu planów (nota bene A. Tomczak nie uwzględnia w swoim katalogu planu sztokholmskiego).

${ }^{16}$ Fragment planu reprodukuje: J. STANKIEwicz, op.cit., s. 52 (il. 22).

${ }^{17}$ A. Томсzак, O najdawniejszych planach Torunia, s. 109-110. 
zauważając, że plan włoski to akwaforta (plan wiedeński to rękopis), i ustalił miejsce jej publikacji ${ }^{18}$. Przyjrzenie się obu planom nie pozostawia raczej wątpliwości, że publikowana w dziejach cesarza Leopolda akwaforta jest przeróbką na cele tej publikacji planu oblężenia Torunia przechowywanego w Kriegsarchiv. Zmiany mają dość zasadniczy charakter, dotyczą m.in. kompozycji planu włoskiego, na którym szeroko ujęte okolice Torunia zostały pokazane w miniaturze, główną treść stanowi natomiast miasto z najbliższą okolicą i wojskami oblegającymi. Dużo uboższa jest też legenda. Poza tym jednak oba plany łączy podobne przedstawienie wielu szczegółów, w tym m.in. fortyfikacji miasta. Nie ulega wątpliwości, że owe przeróbki miały uczynić materiał bardziej atrakcyjnym w skierowanej do szerszego czytelnika publikacji. Konstatacja ta stanowi niewątpliwie interesujący przyczynek do funkcjonowania źródeł kartograficznych w epoce nowożytnej i ciekawych relacji oraz powiązań pomiędzy materiałem stricte militarnym (ergo poniekąd tajnym) a tym, co zostało skierowane do stosunkowo szerokiego odbiorcy.

Jeśli chodzi o opis zewnętrzny planu, to jego struktura jest dość skomplikowana, po części odzwierciedla zabiegi konserwatorskie (podklejenia), najpewniej z XIX w. Jak można przypuszczać, owe zabiegi konserwatorskie, w połączeniu chyba ze świadomością konieczności jakiegoś złożenia planu ze względu na jego rozmiary, spowodowały jego „naturalny” podział na sześć niemal równych sekcji ${ }^{19}$, widoczny w ogólnym spojrzeniu na plan. Dla dalszych rozważań przyjmuję ową de facto sztucznie stworzoną strukturę planu z podziałem na sześć sekcji, z numeracją jednak I-V, ponieważ dawny plan miał nieregularny kształt i wypełnił trzy sekcje w górnej części, a tylko dwie w dolnej (tu pierwsza z lewej sekcja jest pusta, nie zawiera naklejonego starego planu). Ta struktura powstała wskutek naklejenia dawnego planu z XVII w. na lekko pożółkły papier w XIX w. (?), który z kolei został naklejony na kawałek szarego płótna (lub też stary plan z XVII w. naklejono w XIX w. na papier uprzednio podklejony płótnem; kolejność działań w tym przypadku wymagałaby fachowej analizy technologa lub konserwatora papieru lub płótna, co dla naszych rozważań nie jest istotne). Jak się wydaje, następnie - by umożliwić składanie planu - dokonano podziału na sześć prostokątów przez dość brutalne dokonanie wycięć (szczelin) w papierze (tzn. w obu warstwach: starym planie i podkładzie z XIX w.), niezbyt zresztą równych. Widoczne przesunięcia między zwłaszcza sekcją II i IV wskazywałyby może jednak, że najpierw plan, naklejony na nowy papier, podzielono na sekcje, a dopiero potem naklejono na płótno. Reasumując, na ów lekko pożółkły papier z XIX w. naklejono dawny, mocno chyba zniszczony plan. Zrobiono to w sumie dość niestarannie (może zresztą ze

${ }^{18}$ Ibid. oraz s. 123, poz. 16 katalogu. Plan ten jest ilustracją w dziele: Historia di Leopoldo Cesare [...] dall'anno 1656 sino 1669, autorstwa hrabiego Galeazzo Gualdo-Priorato, które ukazało się w 1669 r. w Wiedniu w oficynie Gio. Battista Hacque. Luźna odbitka tego planu znajduje się w Archiwum Państwowym w Toruniu, Kartografia, T. 196, nr 289.

${ }^{19}$ Poszczególne sekcje, licząc od lewej strony, najpierw pas górny, potem dolny, mają następujące wymiary: sekcja I - 57,3 x 42,3 cm; sekcja II - 57 x 42 cm; sekcja III - 57,5 x 43,2 cm; sekcja pusta - 56,5 x 42,3 cm; sekcja IV - 57,2 x 42,2 cm; sekcja V - 57,6 x $42 \mathrm{~cm}$. 
względu na stan planu trudno było lepiej), o czym świadczą liczne fałdki, pomarszczenia itp. Dodatkowo dość niestarannie podklejono paskami dziewiętnastowiecznego papieru brzegi całości tam, gdzie stary plan do brzegów dochodzi.

Jak wspomniano, plan w momencie naklejania był dość mocno zniszczony, widoczne jest kilka dziur i przetarcia na złożeniach. Plan pierwotny był złożony w pionie na trzy razy, w poziomie lewe górne skrzydło (sekcja I) na trzy razy, a potem szersza całość jeszcze na cztery razy. Pierwotnie plan powstał z serii nieregularnej wielkości prostokątów, posklejanych ze sobą na $0,5-1 \mathrm{~cm}$ zakładkę. Lewe górne skrzydło to dwa kawałki plus wąski pasek u dołu. Dalej górą trzy węższe prostokąty tworzą górny rząd. Kolejny rząd to również trzy, ale nieco szersze prostokąty (pierwszy z lewej z małym wcięciem w lewym dolnym rogu). Ostatni dolny rząd to też trzy prostokąty, z których pierwszy z lewej jest węższy, ale ma wypustkę $\mathrm{z}$ lewej strony. $\mathrm{W}$ tym rzędzie ostatni z prawej prostokąt zawiera legendę. $\mathrm{W}$ sekcji II, nad rozdarciem, prawdopodobnie na skutek nadmiaru kleju używanego podczas podklejania, widoczny jest znak wodny, ale trudny do opisania.

Reprodukcja planu ze względu na jego wymiary jest dużym wyzwaniem. Postanowiono go zreprodukować na trzy sposoby: przez wydruk całego planu, co należy traktować jako formę przeglądową; przez wydruk w tym samym formacie poszczególnych pięciu sekcji, wykorzystując w ten sposób sztuczny podział planu dokonany w XIX w., co jednak zwiększa jego czytelność i umożliwia korzystanie $\mathrm{z}$ niego; przez zamieszczenie planu na załączonej płycie DVD.

Niezależnie od edycji planu postanowiono opublikować z komentarzami napisy zamieszczone na planie, głównie tabelaryczną legendę zawierającą 91 pozycji. Teksty na mapie transkrybowano dokładnie wedle pisowni, która wykazuje wiele przeinaczeń, niekiedy uniemożliwiających zrozumienie. W przypadku legendy zrezygnowano $\mathrm{z}$ formy tabeli. Większość numerów jest możliwa do odnalezienia na planie, chociaż zniszczenie mapy powoduje, że niekiedy jest to trudne, w kilku przypadkach niemożliwe. Dla lepszej orientacji każdą z pozycji zaopatrzono w numer sekcji (I-V) wedle przyjętego powyżej podziału. W przypadkach wątpliwych numery zaopatrzono w znak zapytania. Poszczególne punkty zaopatrzono $\mathrm{w}$ niezbędne komentarze objaśniające w przypisach cyfrowych. Ponieważ przypisy dotyczące zewnętrznej krytyki źródła są bardzo nieliczne, zrezygnowano z ich wyodrębniania w postaci przypisów literowych, pozostając przy ciągłej numeracji cyfrowej. 
[435]

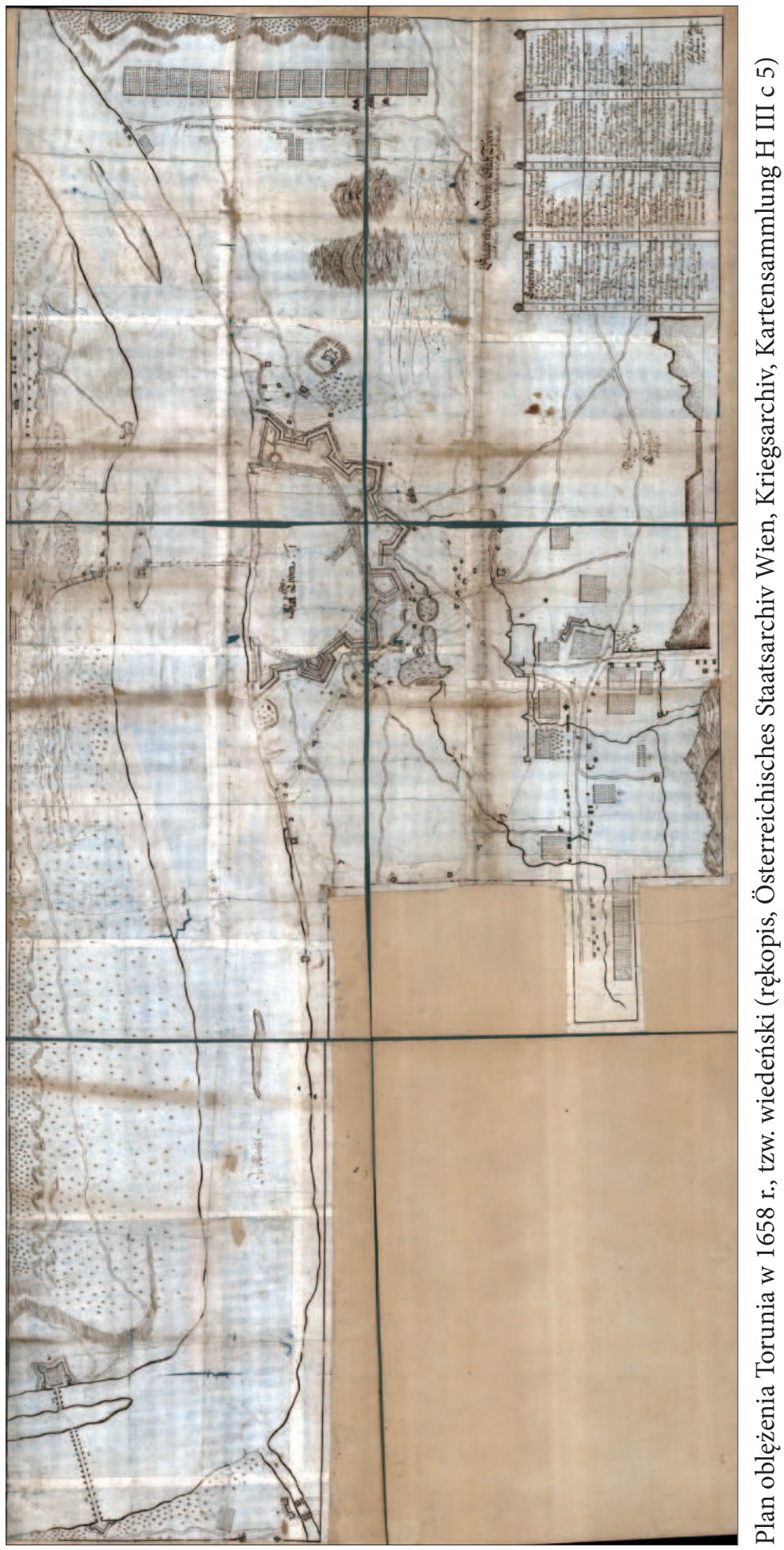

WW w. zapiskihistoryczne.pl 


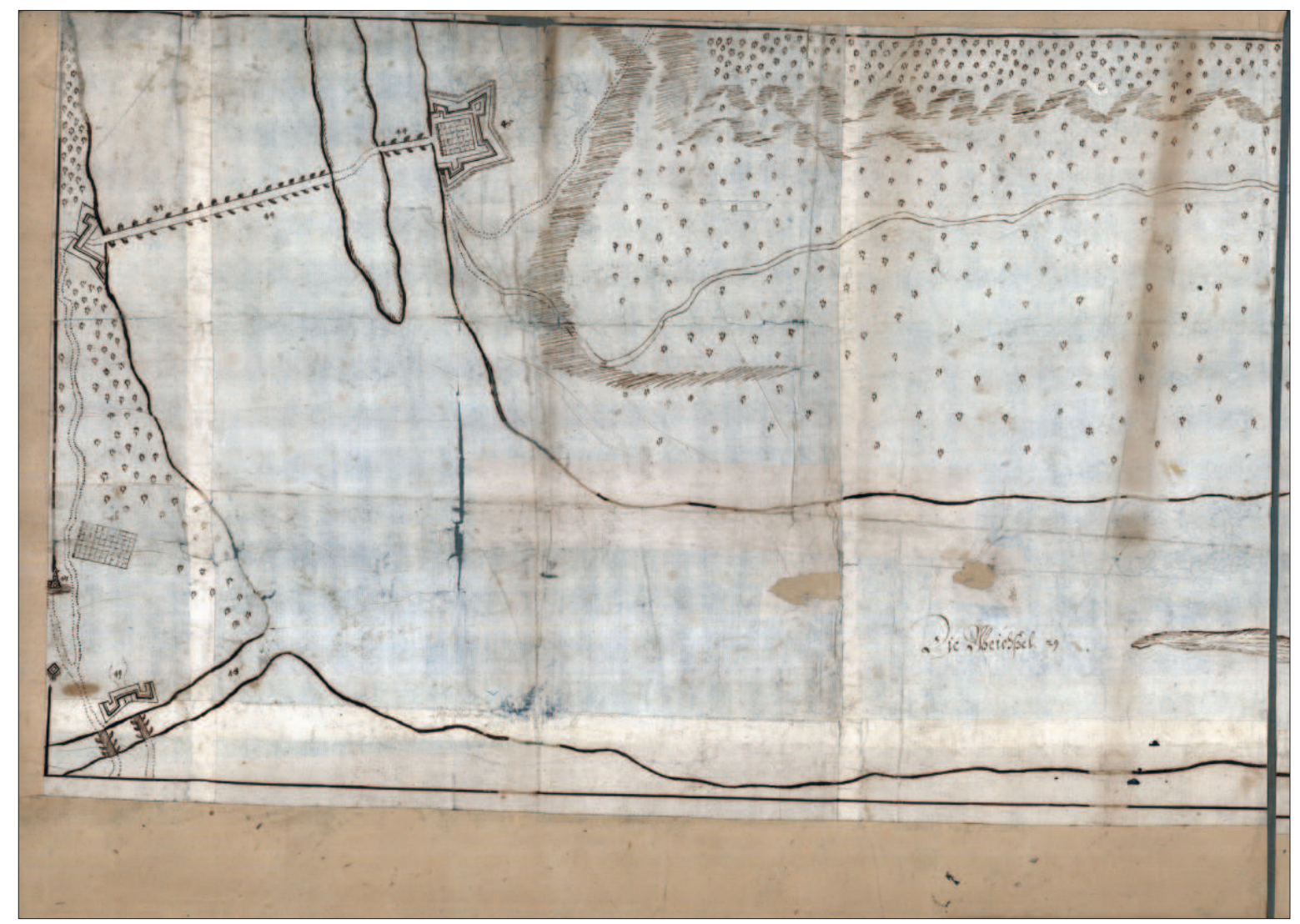

Plan oblężenia Torunia w 1658 r., tzw. wiedeński, sekcja I 


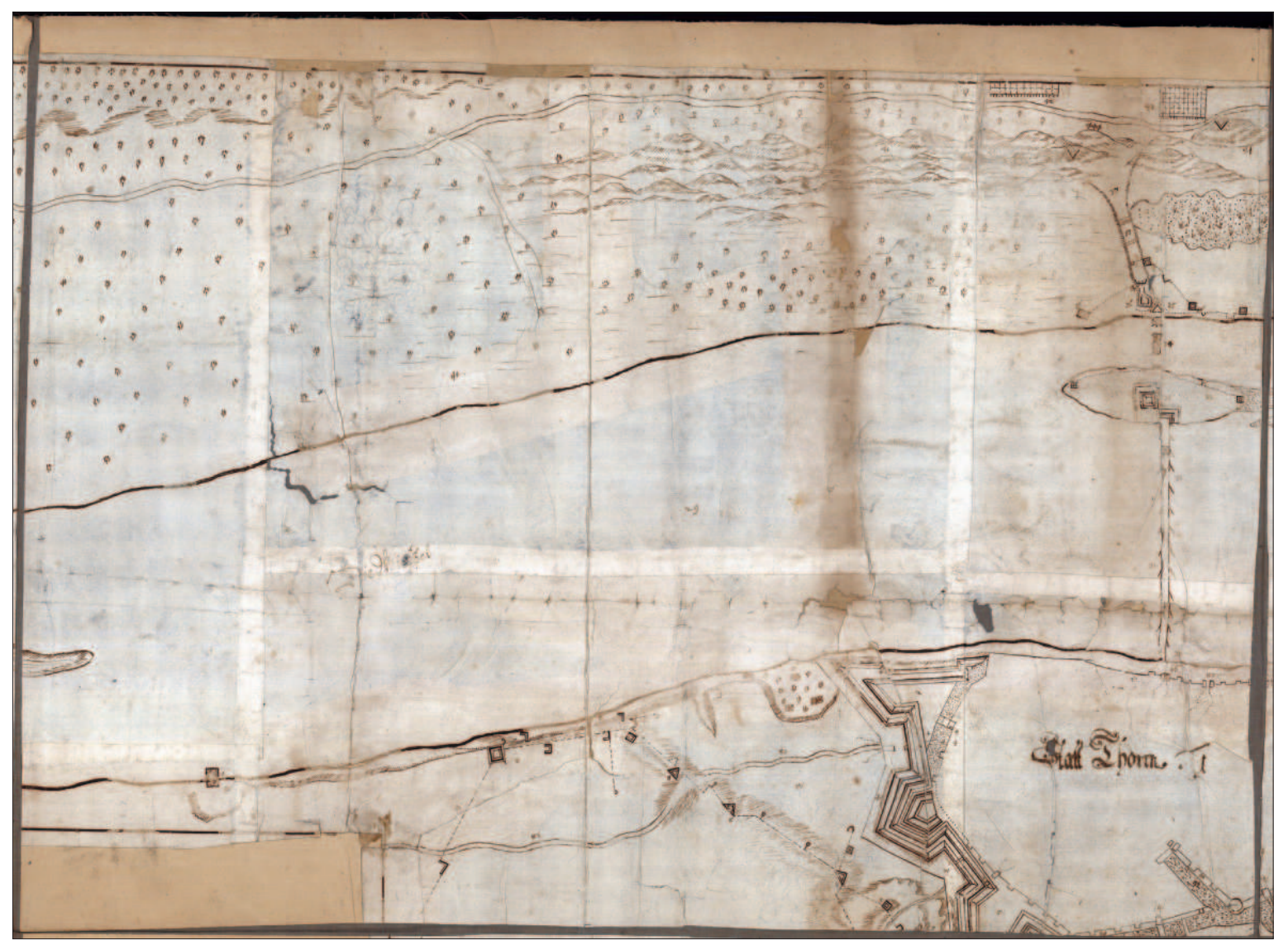

Plan oblężenia Torunia w 1658 r., tzw. wiedeński, sekcja II 


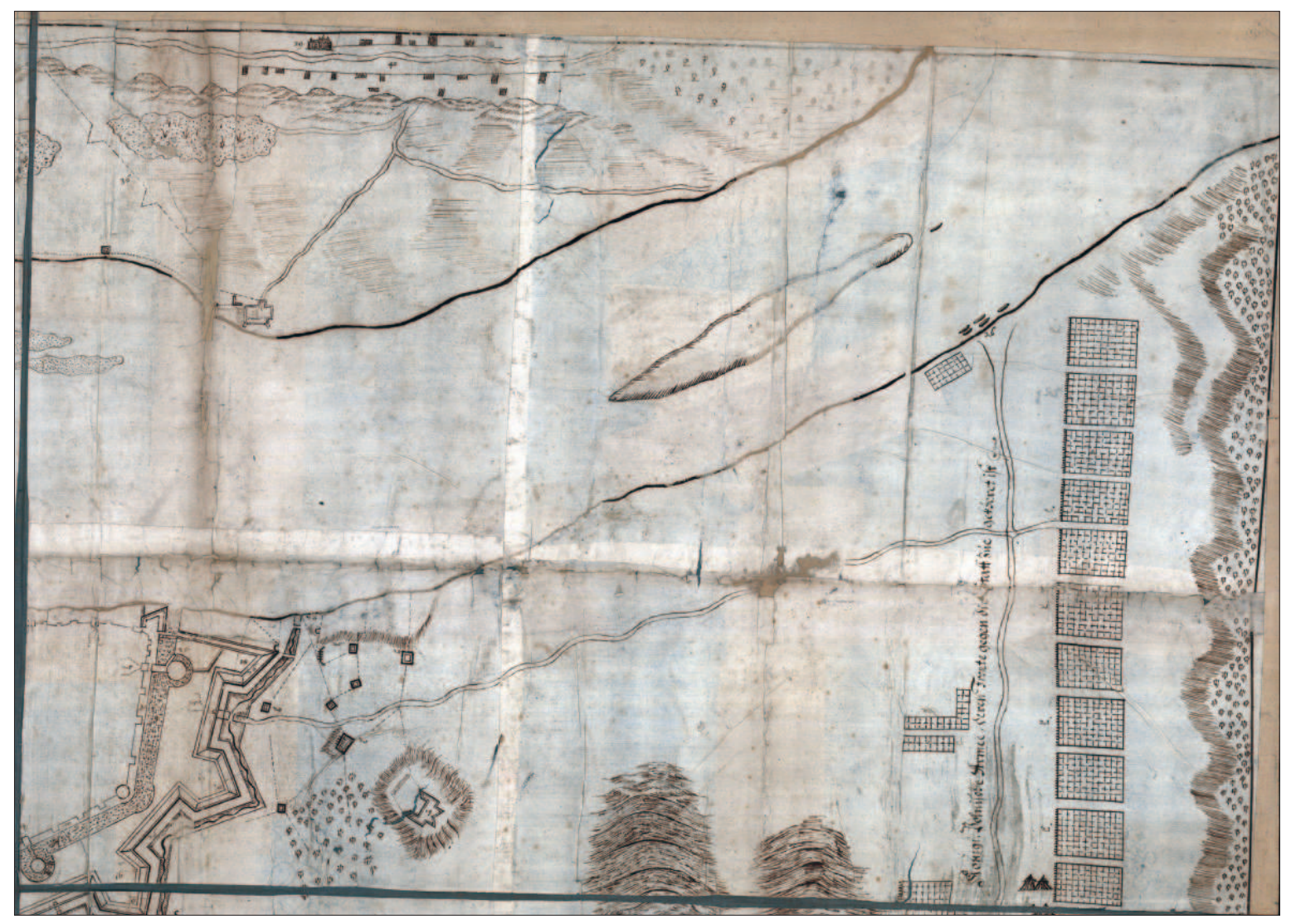

Plan oblężenia Torunia w 1658 r., tzw. wiedeński, sekcja III 


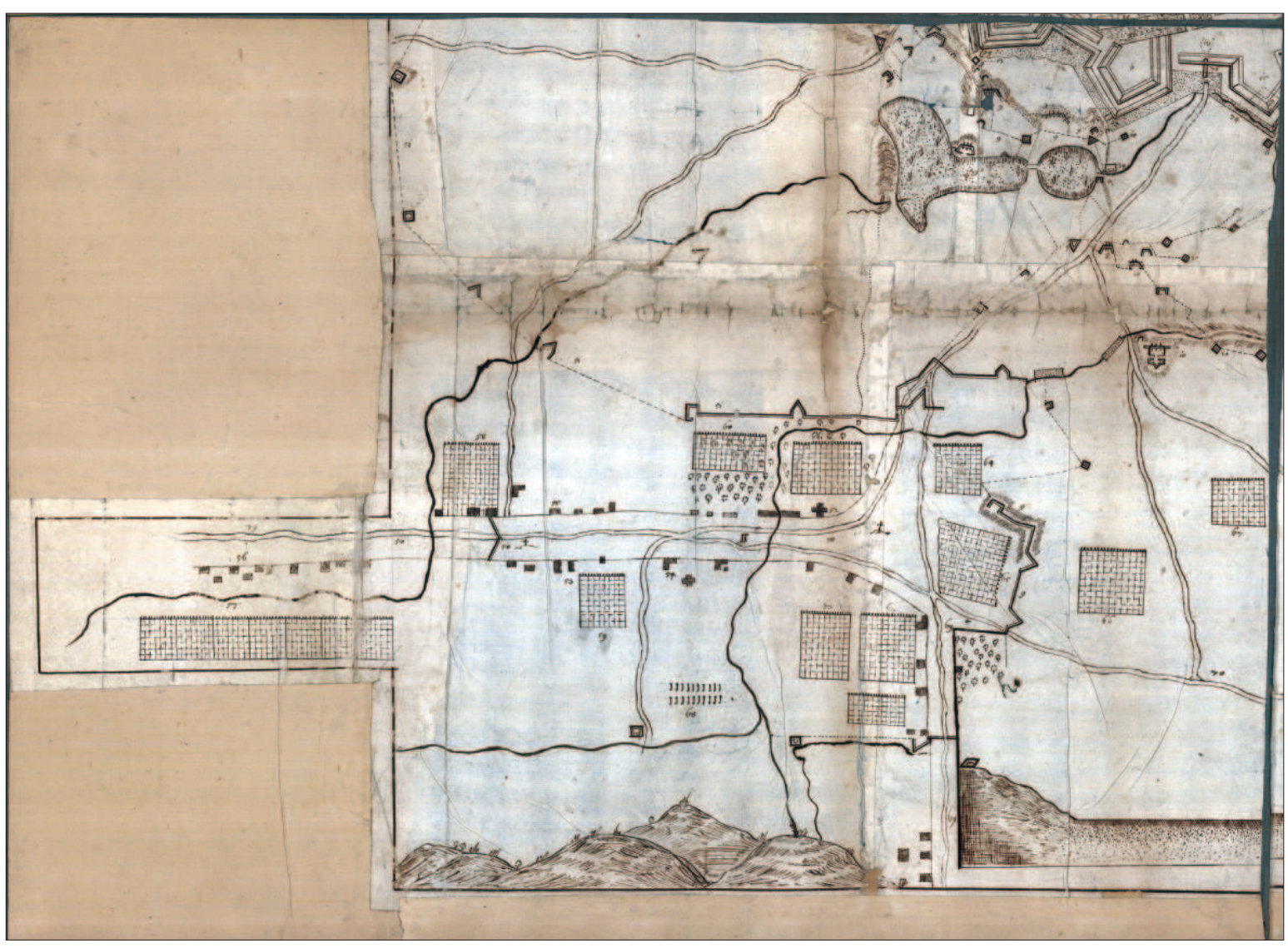

Plan oblężenia Torunia w 1658 r., tzw. wiedeński, sekcja IV 


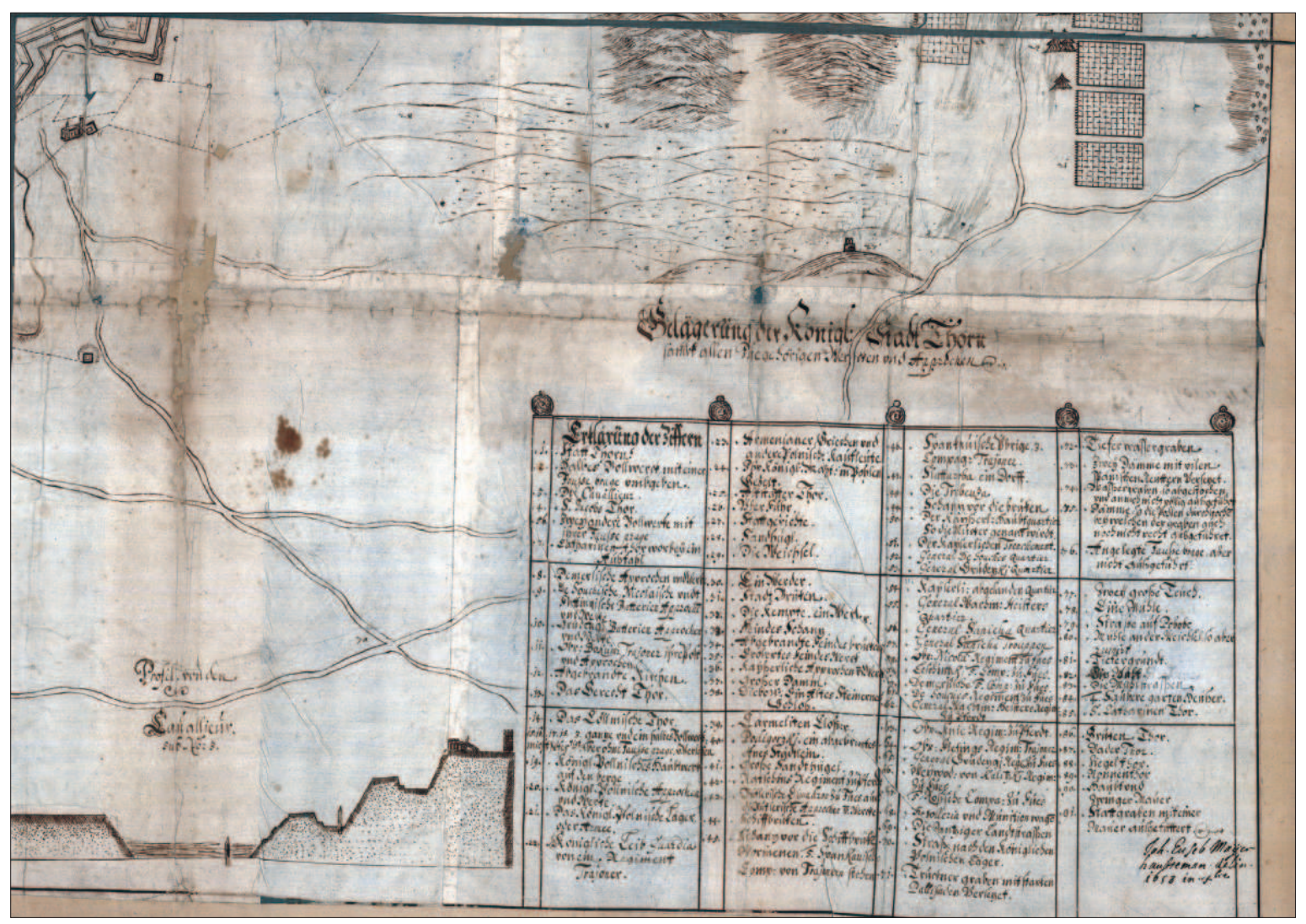

Plan oblężenia Torunia w 1658 r., tzw. wiedeński, sekcja V 


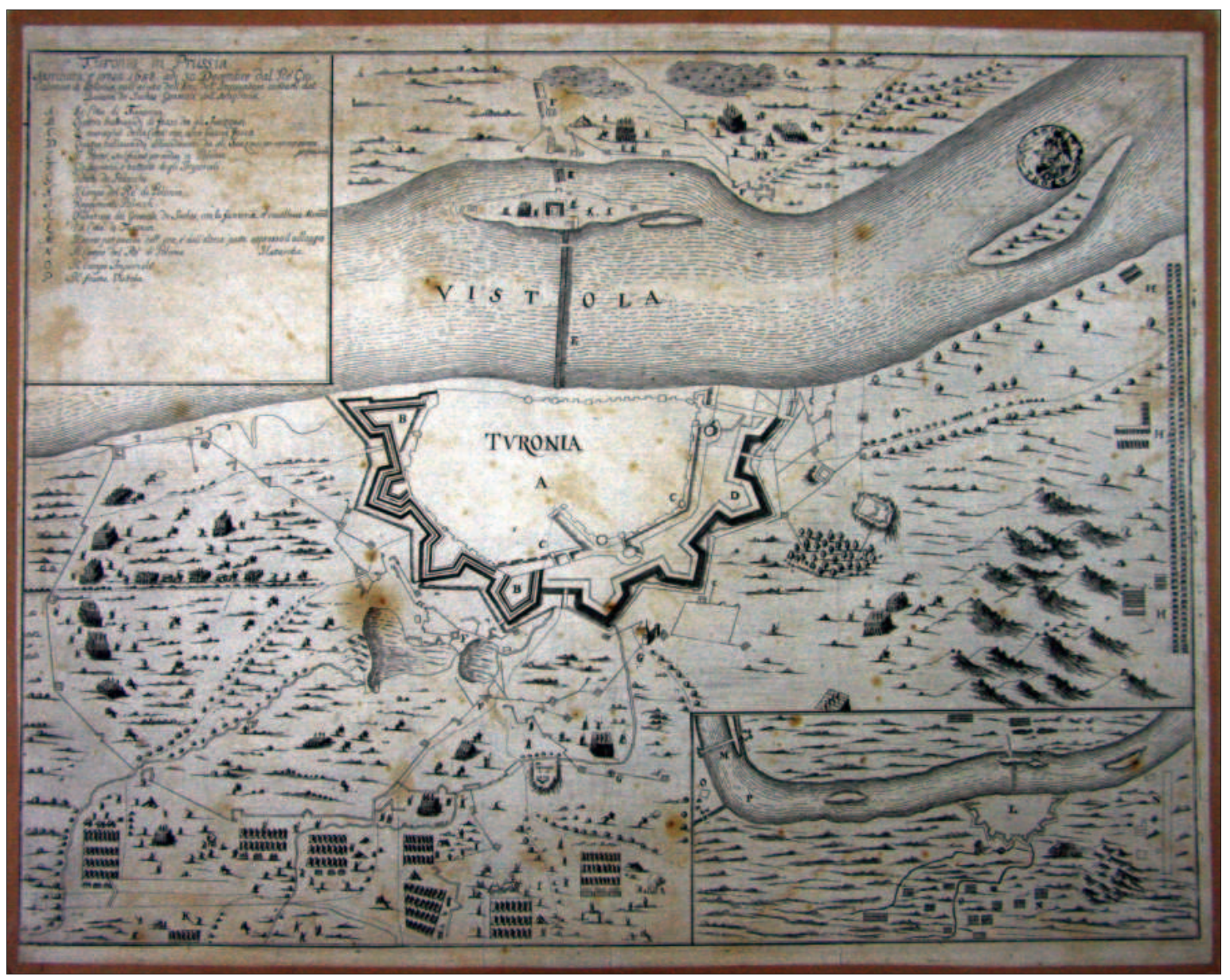

Plan oblężenia Torunia w 1658 r., tzw. włoski (akwaforta, ilustracja w: Galeazzo GualdoPriorato, Historia di Leopoldo Cesare [...] dall'anno 1656 sino 1669, Vienna 1669; odbitka planu z: Archiwum Państwowe w Toruniu, Kartografia, T. 196, nr 289) 


\section{ANEKS ŹRÓDŁOWY}

Napisy na planie oblężenia Torunia w 1658 r., Österreichisches Staatsarchiv Wien, Kriegsarchiv, Kartensammlung H III c 5.

\section{Legenda planu:}

Belägerung der Königl: Stadt Thorn sambt allen zuegehörigen Wercken und Approchen etc.

Erklärung der Ziffern

1. Statt Thorn. [II]

2. Halbes Bollwerck ${ }^{1}$ mit einer Fausse Brage ${ }^{2}$ umbgeben. [II]

3. Der Cavallieur' ${ }^{3}$. [II]

4. S. Jacobs Thor. [II]

5. 6. Zwey andere Bollwerk mit ihrer Fausse Prage. [II, IV]

7. Catharinenthor, worbey ein Außfahl. [II?]

8. Demersische ${ }^{4}$ Approchen und Werke. [II]

9. De Souchische ${ }^{5}$, Nicolaische ${ }^{6}$ undt Flettingische ${ }^{7}$ Batterien, Approchen und Werke. [II, IV]

10. Grüdetzgi ${ }^{8}$ Batterien, Approchen und Werke. [IV]

${ }^{1}$ Chodzi o półbastion przy Woli Zamkowej.

${ }^{2}$ Prawidłowo powinno być: „faussebraie” („braye”), czyli przedwał.

${ }^{3}$ Kawaler, czyli bastion z nadszańcem, podwyższony w ten sposób, ponieważ znajdował się naprzeciw góry św. Jakuba. Na planie jest fałdka, powstała w trakcie naklejania, która zakrywa numer.

${ }^{4}$ Chodzi o pięć kompanii cesarskiego regimentu pieszego barona Franza de Mers, które uczestniczyły w oblężeniu Torunia pod dowództwem podpułkownika barona Franza von Geymanna, zob. Geschichte der K. und K. Wehrmacht. Die Regimenter, Corps, Branchen und Anstalten von 1618 bis Ende des XIX. Jahrhunderts, bearb. v. Major Alphons Freiherrn von WredE, Bd. 1-5, Wien 1898-1905, tu: Bd. 1, Wien 1898, s. 187, 189, 191.

${ }^{5}$ Regiment pieszy dowodzącego wojskami cesarskimi pod Toruniem generała Jean-Louis’a Raduit de Souches, zob. Geschichte der K. und K. Wehrmacht, Bd. 2, Wien 1898, s. 254-257.

${ }^{6}$ Regiment pieszy pułkownika Christopha [de] Nicola; w rzeczywistości pod Toruniem właścicielem regimentu był już i dowodził nim pułkownik Lukas Spieckh Ritter zu Ulbergau und Langenau, zob. Geschichte der K. und K. Wehrmacht, Bd. 2, s. 125.

${ }^{7}$ Cesarski regiment dragonów pułkownika Johanna Flettingera (którym pod Toruniem dowodził podpułkownik Philipp von Longueval), zob. Geschichte der K. und K. Wehrmacht, Bd. 3, Wien 1901, s. 641.

${ }^{8}$ Chodzi najpewniej o stanowiska regimentu pieszego generała artylerii koronnej Krzysztofa Grodzickiego, zob. Jan WIMmer, Wojsko polskie w drugiej połowie XVII wieku, Warszawa 1965, s. 117. 
11. Obr: Bokum Trajoner ${ }^{9}$, ihre Post und Approchen. [IV, V]

12. Abgebrandte Kirchen ${ }^{10}$. [V?]

13. Das Gerecht Thor. [II]

14. Das Cöllmische Thor. [III]

15. 16. 17. 18. 3 gancze und ein halbes Bollwerk nicht ${ }^{11}$ ufertigt $^{12}$, aber ohne Fausse Prage u. verlassen ${ }^{13}$. [III, IV, V]

19. Königl. Pollnisches Haubtwerk auf den Berge. [III]

20. Königl. Pollnische Approchen und Werke. [III]

21. Das Königl. Polnische Läger oder Armee. [III, V]

22. Königliche Leib Guardia von ein Regiment Trajoner ${ }^{14}$. [III, V]

23. Armenianer, Griechen und andere polnische Kaufleute. [III]

24. Ihr Königl. Mayt. in Pohlen Gezelt. [III, V]

25. Altstätter Thor. [III]

26. Überfuhr. [III]

27. Stattgerichte ${ }^{15}$. [V]

28. Sandhügl. [V]

29. Die Weichsel. [I, II]

30. Ein Werder. [III]

31. Stadt Brücken. [II]

32. Die Kempte, ein Werder. [II]

33. Feindes Schancz. [II?]

34. Abgebrandte Feindesbrücken. [II]

35. Erobertes Feindeswerck. [II]

36. Kayßerliche Approchen u. Wercke. [II]

37. Großer Damm. [II]

38. Diebow. Ein altes steinernes Schloß. [III]

39. Carmeliten Closter ${ }^{16}$. [III]

40. Podigorzki, ein abgebrantes offnes Städtlein. [III]

41. Große Sandthügel. [II]

42. Ratschins Regiment zu Pferdt ${ }^{17}$. [II]

\footnotetext{
${ }^{9}$ Chodzi o stanowiska regimentu królewskiego dragonów pod dowództwem pułkownika Jana Henryka von Alten-Bockuma, ibid.

${ }^{10}$ Najprawdopodobniej chodzi o przedmiejski kościół św. Jerzego.

${ }^{11}$ W zasadzie napisane: „micht” [!].

${ }^{12}$ Sylaba „-tigt" nadpisana.

${ }^{13}$ Bastiony frontu zachodniego, które - ponieważ nie były ukończone - nie były przez Szwedów de facto obsadzone i bronione, zostały więc opanowane przez sprzymierzonych podczas szturmu.

${ }^{14}$ Chodzi najpewniej o pieszy regiment gwardii pod dowództwem Fromholda von Ludinghausen Wolffa oraz jeden z polskich regimentów dragońskich, których pod Toruniem były trzy.

${ }^{15}$ Czyli szubienica.

${ }^{16}$ Chodzi o klasztor reformatów w Podgórzu, w którym w czasie oblężenia przebywała królowa Ludwika Maria i krótko również król Jan Kazimierz.

${ }^{17}$ Cesarski regiment kirasjerów pułkownika barona Joachima von Ratschin, zob. Geschichte der K. und K. Wehrmacht, Bd. 3, s. 532.
} 
43. Butlerische Esquadron zu Fues, auch die Butlerische Approchen u. Werk$\mathrm{ke}^{18}$. [II?, III, IV, V]

44. Schiffbrucken. [I]

45. Schancz vor die Schiffbrücke, worinenen 5 Spankauische Comp: von Trajenern stehen ${ }^{19}$. [I]

46. Spankauische übrige 3 Compag: Trajoner. [I]

47. Slattaroba ${ }^{20}$, ein Dorff. [I]

48. Die Trebeuza ${ }^{21}$. [I]

49. Schancz vor die Brücken. [I]

50. Der Kayßerl: Haubtquartier, so die Mucker genantwirdt. [IV]

51. Der Kayserlichen Trenchement. [IV]

52. General De Souches Quartier. [IV]

53. General Grudeczki Quartier. [IV]

54. Kayserli: Abgesanden Quartier ${ }^{22}$. [IV]

55. General Wachm: Heisters ${ }^{23}$ Quartier. [IV]

56. General Sapieha ${ }^{24}$ Quartier. [IV]

57. General Sapieha Trouppen. [IV]

58. Obr: Nicola Regiment zu Fues ${ }^{25}$. [IV]

59. Leschintzki 5. Comp: zu Fues ${ }^{26}$. [IV]

60. Demersische 5 Comp. zu Fues ${ }^{27}$. [IV]

61. De Souches Regiment zu Fues ${ }^{28}$. [IV]

62. General Wachtm: Heisters Regim: zu Pferdt ${ }^{29}$. [IV]

63. Obr: Knie Regim: zu Pferdt ${ }^{30}$. [IV]

${ }^{18}$ Wedle Jana Wimmera (op.cit., s. 116) pod Toruniem był regiment pieszy generała majora Wilhelma Butlera. Jego pozycje są zaznaczone na opuszczonych przez Szwedów nieukończonych bastionach frontu zachodniego.

${ }^{19} \mathrm{~W}$ tym i następnym punkcie kompanie cesarskiego regimentu dragonów pułkownika barona Parisa von Spankau, zob. Geschichte der K. und K. Wehrmacht, Bd. 3, s. 642.

${ }^{20}$ Do tego stopnia zniekształcono nazwę podtoruńskiej wsi Złotoria.

${ }^{21}$ Tak została zniekształcona nazwa rzeki Drwęcy.

${ }^{22}$ Kwatera posła cesarskiego Franza Paula de Lisoli.

${ }^{23}$ Generał baron Gottfried von Heister był szefem regimentu kirasjerów, którym pod Toruniem dowodził podpułkownik Otto Wilhelm von Berlepsch (Berlibs), zob. Geschichte der K. und K. Wehrmacht, Bd. 3, s. 547.

${ }^{24}$ Pisarz polny koronny Jan Sapieha był jednym z polskich dowódców pod Toruniem. Jego szefostwa był jeden $\mathrm{z}$ regimentów dragonii i pułk jazdy, złożony z lekkich chorągwi (J. WimMER, op.cit., s. 117).

${ }^{25}$ Zob. przyp. 6.

${ }^{26}$ Chodzi o kompanie z regimentu piechoty podkanclerzego koronnego Bogusława Leszczyńskiego (J. WIMMER, op.cit., s. 117).

${ }^{27}$ Zob. przyp. 4.

${ }^{28}$ Zob. przyp. 5.

${ }^{29}$ Zob. przyp. 23.

${ }^{30}$ Cesarski regiment kirasjerów pułkownika (lub generała - Obrist General-Feldwachtmeister) barona Jobsta Hilmara von Knigge, zob. Geschichte der K. und K. Wehrmacht, Bd. 3, s. 583. 
64. Obr: Fletings Regim: Trajoner ${ }^{31}$. [IV]

65. General Grudeczgi Reg. zu Fues ${ }^{32}$. [IV]

66. Weywod: von Kalitzki Regim: zu Fues ${ }^{33}$. [IV]

67. 5 Rosische Compa: zu Fues ${ }^{34}$. [IV]

68. Artolleria und Munitionwagen. [IV]

69. Die Dantziger Landtstrasßen. [IV]

70. Straße nach den Königlichen Polnischen Läger. [IV, V]

71. Truckner Graben mit starken Pallissaden verseczet. [II]

72. Tiefer Wassergraben. [IV]

73. Zwey Dämme mit vilen spänischen Reüttern verseczet. [IV]

74. Wasßergraben, so abgestochen und annoch nicht völlig außgeführt. [IV, V]

75. Dämme, so die Pohlen durchstochen, bey welchen der Graben auch noch nicht recht außgeführet ${ }^{35}$. [III]

76. Angelegte Fausse Brage, aber nicht außgeführt ${ }^{36}$. [III, IV]

77. Zwey große Teüch. [IV]

78. Eine Mühle ${ }^{37}$. [IV]

79. Strasse auf Pobobe ${ }^{38}$. [IV]

80. Mühle an der Weichsel, so aber ruinirt ${ }^{39}$. [II]

81. Tiefer Grundt ${ }^{40}$. [II]

82. Ein Walt ${ }^{41}$.

83. Die Mühlstrasßen. [II]

84. 4 saubere Garten Heüßer ${ }^{42}$. [II?]

85. S. Catharinen Thor. [II $]^{43}$

86. Brüken Thor. [II]

87. Bader Thor. [II]

${ }^{31}$ Zob. przyp. 7.

${ }^{32}$ Zob. przyp. 8. s. 117).

${ }^{33}$ Regiment piechoty wojewody kaliskiego Andrzeja Karola Grudzińskiego (J. Wimmer, op.cit.,

${ }^{34}$ Tej jednostki nie udało się zidentyfikować.

${ }^{35}$ Udało się ustalić jeden numer w fosie fortyfikacji bastionowych w pobliżu Bramy Starotoruńskiej. Liczba mnoga wskazuje jednak, że było tych obiektów więcej, tylko w obecnym stanie planu trudno je odszukać. Chodziło tu o zapory pozwalające utrzymywać poziom wody w fosach fortyfikacji ziemnych. Ich przerwanie ułatwiło - jak się wydaje - opanowanie bastionów.

${ }^{36}$ Przy bastionach o numerach na planie od 15 do 18 zaplanowany został przedwał („,faussebraie"), ale nie został przez Szwedów wykonany.

${ }^{37}$ Pozycja 77 i 78 to stawy i młyn Kaszownik.

${ }^{38}$ Chodzi najprawdopodobniej o podtoruńską miejscowość Papowo (Toruńskie).

${ }^{39}$ Młyn położony w pewnym oddaleniu od miasta, w górę rzeki.

${ }^{40}$ Określenie dla obszaru między miastem oraz fortyfikacjami bastionowymi a górą św. Jakuba.

${ }^{41}$ Poprawione prawdopodobnie z: „Walt Straßsen” (ostatnie słowo wydrapane). Nie udało się zlokalizować tego numeru na planie.

${ }^{42}$ Numeru nie udało się zlokalizować. Prawdopodobnie chodzi o wydzielony graficznie obszar bezpośrednio na przedpolu półbastionu przy Woli Zamkowej, nad Wisłą.

${ }^{43}$ Numer niewidoczny, ale miejsce łatwe do zlokalizowania. 
88. Ziegelthor ${ }^{44}$. [III]

89. Nonnenthor. $[\mathrm{III}]^{45}$

90. Haubt und Zwinger Mauer. [II, III, IV]

91. Stattgraben mit einer Mauer ausgefüttert. [II, III, IV]

Joh. Euseb Mayer Haubteman delin. 1658 in Xbre ${ }^{46}$

\section{Inne napisy na planie:}

Die Weichßel ${ }^{47}$

Statt Thorn $1^{48}$

Profil von den Cauallieur sub No: $3 .{ }^{49}$

Konigl. Polnische Armee, deren Fronte gegen die Statt zue gekheret ist. ${ }^{50}$

prof. dr hab. Bogusław Dybaś

Stacja Naukowa PAN w Wiedniu

e-mail:dybas@viennapan.org

\footnotetext{
${ }^{44}$ Chodzi oczywiście o Bramę Żeglarską (Seglertor). Numer niewidoczny.

${ }^{45}$ Numer niewidoczny.

${ }^{46}$ Podpis inną ręką niż napisy na planie (własnoręczny), ciemniejszym atramentem.

${ }^{47}$ Napis umieszczony dwukrotnie, ale raz słabo widoczny ze względu na uszkodzenie papieru; za pierwszym razem z numerem 29 legendy.

${ }^{48}$ Napis umieszczony w środku planu miasta; numer odnosi się do legendy.

${ }^{49}$ Napis umieszczony nad przekrojem wału Kawalera, między terenem Mokrego a tabelą z legendą, częściowo w sekcji IV, częściowo V; na rysunku widać, jak przedstok fortyfikacji („glacis”) wchodzi niejako we wzniesienie, czyli górę św. Jakuba.

${ }^{50}$ Napis w sekcji III, pionowo, wzdłuż polskich pozycji.
} 


\section{EIN PLAN DER BELAGERUNG VON THORN IM JAHR 1658 AUS DEM KRIEGSARCHIV IN WIEN}

\section{Zusammenfassung}

Schlüsselwörter: schwedische Kriege, Militärkartografie, Befestigungen, kaiserliche Armee, polnische Armee, Weichsel, 17. Jahrhundert, Krieg 1655-1660, Johan Eusebius Mayer

Der im Wiener Kriegsarchiv aufbewahrte Plan ist ein hervorragendes Zeugnis für eines der wichtigsten Ereignisse des polnisch-schwedischen Kriegs in den Jahren 1655-1660. Angesichts seiner Ausmaße stellt er nicht nur sehr genau die Stadt dar, sondern auch ihre Umgebung, zahlreiche Details und die Positionen der belagernden Heere (vor allem der kaiserlichen). Ausgestattet ist er mit einer Legende von 91 Positionen. Außerdem ist er signiert: Er trägt die Unterschrift seines Urhebers Johan Eusebius Mayer. Er bildet eine wertvolle Quelle für Forschungen zu den Befestigungen Thorns in der Zeit der schwedischen Kriege. Es konnte festgestellt werden, dass der Plan die Grundlage des sog. Italienischen Plans der Belagerung von Thorn war, einer Radierung in einer 1669 auf Italienisch herausgegebenen Geschichte Kaiser Leopolds I.

\section{THE PLAN OF THE SIEGE OF TORUN IN 1658 FROM THE VIENNA ARCHIVE OF WAR}

\section{Summary}

Key words: the Swedish wars, military cartography, fortifications, the emperor's army, the Polish army, the Vistula river, the war of 1655-1660, Johan Eusebius Mayer

The plan of the siege of Torun, preserved in the Vienna Archive of War (Kriegsarchiv) is the perfect documentation of one of the most important events of the Polish-Sweden war of 1655-1660. It includes a detailed presentation of the city and its suburbs, along with numerous details and the positions occupied by the besieging army (in particular the emperor's army). It includes a key with 91 entries. It is signed by its author - Johan Eusebius Mayer. The document is a valuable source for research on Torun's fortifications during the times of the Swedish wars. It has been established that the plan was a basis for the so called Italian plan of the siege of Torun - the etching included in the history of Emperor Leopold I published in the Italian language in 1669. 